\title{
Çiftçilerin Arazi Kullanım Türlerine Karar Vermelerinde Etkili Olan Faktörlerin Analizi: Kumkale Ovası Örneği
}

\author{
Bengü EVEREST ${ }^{1 *}$ (D) Timuçin EVEREST ${ }^{2}$ \\ ${ }^{1}$ Çanakkale Onsekiz Mart Üniversitesi, Ziraat Fakültesi Tarım Ekonomisi Bölümü, Çanakkale/TURKEY \\ ${ }^{2}$ Çanakkale Onsekiz Mart Üniversitesi, Lapseki Meslek Yüksekokulu, Çanakkale/TURKEY \\ ${ }^{1}$ https://orcid.org/0000-0003-4301-9337 $\quad{ }^{2}$ https://orcid.org/0000-0002-3670-2114 \\ * Corresponding author (Sorumlu yazar): beverest@comu.edu.tr \\ Received (Geliş tarihi): 26.06.2020Ａccepted (Kabul tarihi): 29.07.2020
}

\begin{abstract}
ÖZ: Çiftçiler bazı faktörlerin etkisiyle arazi kullanım türlerini belirlemektedirler. Bu çalışmada Çanakkale ilinde önemli bir üretim bölgesi olan Kumkale ovasındaki çiftçilerin arazi kullanım türlerine karar verme süreçleri bulanık eşli karşılaştırma (BEK) ile analiz edilmiştir. Bu amaçla Kumkale ovasında üretim yapan 114 çiftçi ile anket çalışması yapılmıştır. Çiftçilerin arazi kullanım türlerine karar vermelerinde en etkili olan faktör üretimin maliyeti $(0,50)$ olarak tespit edilmiştir. Bunu sirastyla ürünleri pazarlama kolaylığı $(0,48)$, toprak özelliği $(0,36)$ ve çiftçilerin üretim alışkanlıkları $(0,28)$ takip etmektedir. Buna göre yapılacak üretim planlamalarında ürünün maliyetinin, pazarlama olanaklarının ve toprak özelliklerinin dikkate alınmasi tavsiye edilmektedir.
\end{abstract}

Anahtar Kelimeler: Bulanık eşli karşılaştırma, ürün deseni, arazi kullanımı, karar verme.

\section{Analysis of Factors Affecting Farmers' Decision on Land Use Types: The Case of Kumkale Plain}

\begin{abstract}
Farmers determine the land use types with the effect of some factors. In this study, the decision-making processes of the farmers in Kumkale plain, which is an important production area in Çanakkale province, were analyzed by using fuzzy paired comparison (BEK) method. For this purpose, a survey was conducted with 114 farmers producing in Kumkale plain. The most effective factor for the farmers to decide on the land use types was determined as the cost of the production (0.50). This is followed by the ease of marketing the products (0.48), the soil properties $(0.36)$ and the production habits of the farmers (0.28). Accordingly, it is recommended to consider the cost, marketing opportunities and soil properties of the product in production planning.
\end{abstract}

Keywords: Fuzzy paired comparison, crop pattern, land use, decision making.

\section{GíRiş}

Doğal kaynaklar doğru ve sürdürülebilir şekilde yönetilebildiğinde insanların ihtiyaçlarına cevap verebilmektedir. Arazi yönetim uygulamaları ve doğal kaynak bileşenlerinin insan kullanımı için dönüştürülmesi arazi kullanım ve arazi örtüsünde çok fazla değişime sebep olmuştur. Bu farklılaşmalar sonucunda dünyadaki arazilerin büyük bir çoğunluğu değişim geçirmiştir (Foley ve ark., 2005). Arazi kullanım türlerinin belirlenmesinde teknik şartların etkisinin yanı sıra sosyo-ekonomik özelliklerin de etkisi bulunmaktadır.

Arazi kullanımı sosyal ve ekonomik koşullar tarafından yönetilen dinamik bir süreç olduğundan, sosyo-ekonomik koşullar ile arazi kullanımı arasındaki ilişkiyi anlamak ve daha sonra arazi 
kullanıcılarının doğru stratejiyi uygulamasına olanak verecek şekilde sosyo-ekonomik koşulları düzenlemek gerekmektedir (Ganzert, 1995; Zander ve Kächele 1999). Arazilerin yönetilmesinde birçok sosyal kural olduğu bilenmektedir. $\mathrm{Bu}$ sosyal kurallar mülkiyet ve arazi kullanım uygulamalarını parsel düzeyine kadar etkilenmesini sağlamaktadır. Bu hiyerarşik sistemde çiftçilerin kararları köyde yaşayan grupların kaynakları korumak ve sürdürülebilirlik adına aldıkları kararlar ile sıkı bir şekilde benzerlik göstermektedir (Balent ve Smith, 1993; Bourbouze ve Gibon, 1999; Mottet ve ark., 2006). Karar verme bir eylemin veya düşüncenin diğer seçenekler arasından seçilmesi süreci olarak tanımlanabilir. Karar verme süreci amacın belirlenmesi ve sorunun tanımlanması, önceliklerinin belirlenmesi, alternatif belirleme, değerlendirme ve seçim kriterlerine göre tercihin yapılması olarak tanımlanabilir (Klein ve ark., 1993). Neumann ve Morgenstern (1947)'nin geleneksel fayda teorisi, üreticilerin kesinlik ya da kesinlik eşdeğeri altında, net çiftlik gelirini maksimize etmek gibi tek bir hedefle kararlar verdiğini varsaymaktadır (Baijmol, 1972). Üreticilerin karar süreçleri sosyo-ekonomik faktörlerin etkisi, teknik gözlem ve deneyimlerin sonucu ile toplumun çoğunluk etkisi altında alınan kararlara göre şekillenmektedir. Literatürde çiftçilerin karar verme süreçleri hakkında çalışmalar bulunmaktadır. Abacı ve Demiryürek (2019) sebze yetiştiricilerinin ürün desenlerini belirlemede etkili olan faktörleri araştırmışlardır. Buna göre çiftçilerin ürün desenlerini planlarken etkilendikleri en önemli faktör ürün özelliği ile ilişkilidir. Ancak, çiftçiler üretecekleri ürünlere karar verirken sadece ürün özelliklerinden değil aynı zamanda ellerinde olmayan farklı koşullardan da etkilenmektedirler. Mottet ve ark., (2006) Fransa'da dağlık ve sarp arazi koşullarında çiftçilerin arazi kullanım kararlarının nasıl değiştiğini incelemişlerdir. Arazinin topoğrafik koşullarının esas alındığı çalışmada çiftçilerin karar vermelerini sağlayan faktörlerin başında arazilerin eğim ve yükseklik sınıfları olurken bunun yanında arazinin köye olan uzaklığı ve parseller arasındaki uzaklıkta arazi kullanım değişimini etkilemiştir. Ravnborg ve Rubiano (2013) Kolombiya'da gerçekleştirdikleri çalışmalarında çiftçilerin yöredeki çeşitli toprak koşulları hakkında ayrıntılı bilgiye sahip olmalarına rağmen, toplam arazi büyüklüğü, pazar ve girdi ile ilgili kaygılar gibi diğer faktörlerin, çiftçilerin gerçek arazi kullanım türü ve ürün deseni tercihlerinin oluşmasında daha öne çıkan faktörler olduğunu ortaya koymuşlardır.

Bu çalışma Çanakkale'nin önemli ovalarından biri olan Kumkale ovasında tarımsal üretim yapan üreticilerin arazilerinde yetiştirecekleri ürünleri belirlerken hangi faktörlerin etkisi ile karar verdiğinin belirlenmesi amaçlanmıştır.

\section{MATERYAL ve METOT MATERYAL}

Çanakkale ilinin temel geçim kaynağı tarımdır. Çanakkale ili sahip olduğu arazi varlığı, iklimi, su ürünleri potansiyeli ve hayvan varlığı ile bölgede ve ülke genelinde önemli bir yere sahiptir (Anonim, 2018). Bu çalışma, Çanakkale ilinin önemli ovalarından biri olan Kumkale ovas1 sınırları içerisindeki köylerde yürütülmüş̧ür. $\mathrm{Bu}$ köylerde sulu tarım koşullarında polikültür tarım yapılmaktadır. Çalışma bölgesi kapsamındaki bu köyler aşağıda gösterilmiştir (Şekil 1).

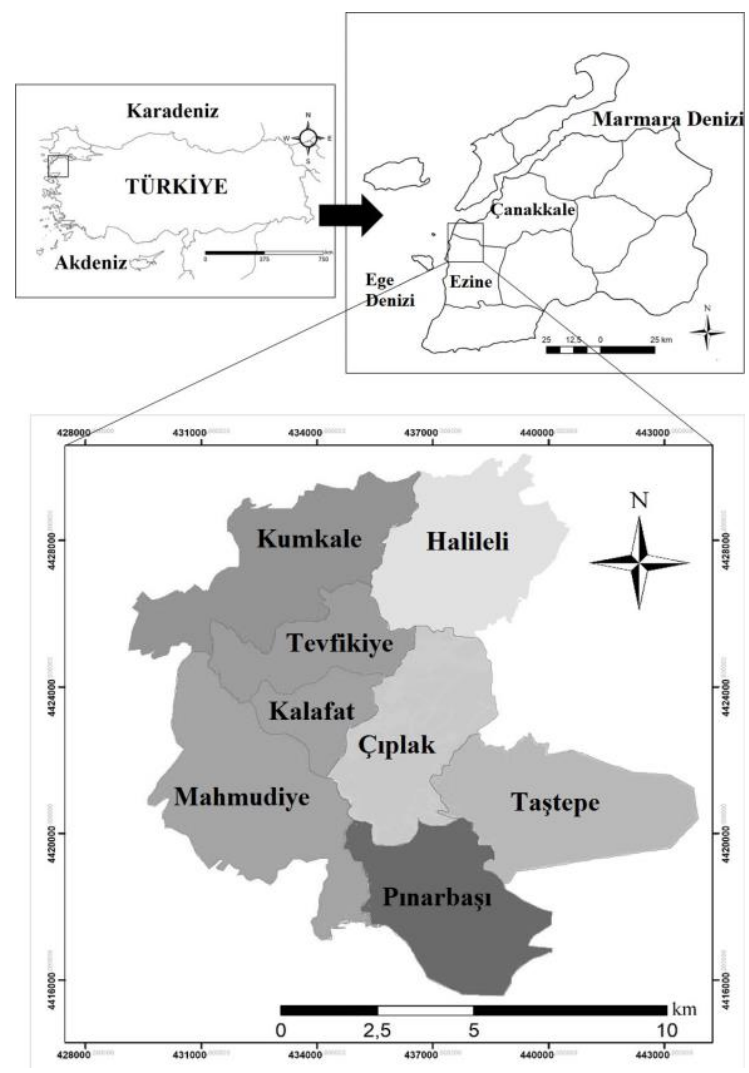

Şekil 1. Çalışma alanı.

Figure 1. Study area. 
$\mathrm{Bu}$ çalıșmanın ana materyali Çanakkale ili Kumkale Ovasında bulunan köylerdeki çiftçiler ile yüz yüze görüşmelerle toplanan birincil nitelikli verilerdir. Çalışmada ayrıca daha önceden yapılan tez, makale vb. yayınların sonuçları ile Tarım ve Orman Bakanlığı verileri de kullanılmıştır.

Çalışma bölgesi kapsamındaki Kumkale, Tevfikiye, Halileli, Kalafat, Çıplak, Mahmudiye, Pınarbaşı, Yeniköy ve Taştepe köylerindeki üretici sayıları çalışmanın populasyonunu oluşturmuştur. Örnek hacmi oransal örnek hacmine göre belirlenmiştir (Newbold, 1995).

$n=\frac{N p(1-p)}{(N-1) \operatorname{var}^{2} p x+p(1-p)}$

Örnek hacminin belirlenmesinde $\% 90$ güven aralığı ve $\% 7,5$ hata payı kullanılmıştır. Böylece örnek hacmi 114 olarak belirlenmiştir. Belirlenen örnekleme sayısı köylerdeki üreticiler arasında oransal olarak dağıtılmıştır.

\section{METOT}

Çalışmada ilk olarak üreticilerin sosyo-ekonomik özellikleri ile işletme özelliklerine ilişkin temel tanımlayıcı istatistikler ve oranları verilmiștir. Çiftçilerin arazi kullanım türlerine karar vermede etkili olan faktörlerin belirlenmesinde bulanık eşli karşılaştırma (BEK) yöntemi kullanılmıştır.

BEK, 1965 yılında Zadeh tarafından geliştirilmiş bir yöntemdir. Bulanık küme teorisinin merkezi bir kavramı kısmi üyelik kavramıdır. Yöntemde standart üyelik teorisinde her bir elemanın olması (1 olmas1) ya da olmamasi ( 0 olması) hali belirlenirse yöntem iyi tanımlanmış olur. Kısmi üyelikte, bulanık küme kapalı aralıkta yani $[0,1]$ aralığında bulunmaktadır. Sonuç olarak küme elemanlarına $0-1$ arasında bir değer belirlenmektedir (Zadeh, 1965). Yöntemde birinci aşama, veri toplamadır. Veri toplama aşamasında aşağıdaki diyagram kullanılmaktadır (Şekil 2).

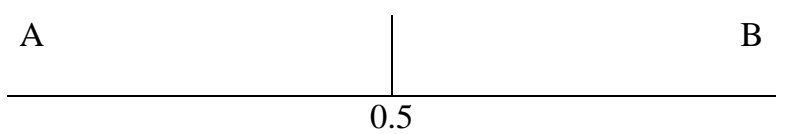

Şekil 2. A ve B arasında karşıllaştırma yapmak amacıyla kullanılan bulanık eşleme yaklaşımı.

Figure 2. Fuzzy matching approach used to compare between A and B.
A ve B amaçları, çizginin zıt taraftaki uçlarına yerleştirilmektedir. Çiftçilerden tercihini belirtmek üzere çizginin üzerine $\mathrm{X}$ işareti koyması istenmektedir. Amaçlar karşılaştırılırken; hangi amaç $\mathrm{X}$ işaretine daha yakın mesafede ise, onun diğerine tercih edildiği söylenebilir. B'ye göre A'nın tercih derecesi (RAB), x işaretinden A'ya olan uzaklıkla ölçülür. A'dan B'ye toplam uzaklık 1' dir.

$$
\begin{aligned}
& \text { Eğer } \mathrm{RAB}<0,5 \text { ise } \mathrm{B}>\mathrm{A} \\
& \text { Eğer } \mathrm{RAB}=0,5 \text { ise } \mathrm{A} \approx \mathrm{B} \\
& \text { Eğer } \mathrm{RAB}>0,5 \text { ise } \mathrm{A}>\mathrm{B}
\end{aligned}
$$

Kesin tercihler olması durumunda $\mathrm{RAB}=1$ veya $\mathrm{RAB}=0$,

Amaçlara ait eşli karşılaştırmaların sayısı, K, aşağıdaki gibi belirlenmektedir.

$K=n *(n-1) / 2$

Burada n, amaçların sayısını ifade etmektedir. Her bir eşli karşılaştırma için, Rij ( $i \neq j$ ) elde edilir. i ye göre $\mathrm{j}$ 'nin tercih derecesinin ölçümü de: $\mathrm{Rji}=1-\mathrm{Rij}$ şeklinde olacaktır.

İkinci olarak, tercihlerin bulanık matrisi oluşturulur. Veriler toplanır ve işlendikten sonra çiftçilerin bulanık tercih matrisi oluşturulur. Sonra verilen bulanık tercih matrisi ile yöntem açıklanır.

$$
\mathrm{R}=\left[\begin{array}{ccccccc}
0 & r 12 & r 13 & , & , & , & r 1 j \\
r 21 & 0 & r 23 & , & , & , & r 2 j \\
r 31 & r 32 & , & , & , & , & , \\
, & , & , & , & , & , & , \\
, & , & , & , & , & , & , \\
, & , & , & , & , & 0 & r i-1 \mathrm{j} \\
r \mathrm{ij} & r i 2 & , & , & , & r \mathrm{ij}- & \\
& & & & & & 0
\end{array}\right]
$$

Sonraki aşamada bulanık ağırlıklı değerler belirlenir. Aşağıdaki formüle göre belirlenen amaçların yoğunlukları tek tek hesaplanır.

$l j=1-\left(\sum_{i=1}^{n} R i j^{2} /(n-1)\right)^{1 / 2}$

Daha sonra amaçlar sıralanır. $I_{j}$ sonuçları 0-1 arasında değişir. Sonuçlar 1'e ne kadar yakınsa 
amaçların tercih yoğunlukları o kadar büyük olarak yorumlanır. BEK sonucu elde edilen verilerinin değerlendirilmesinde Kendall's W testi ile Friedman testi dikkate alınmıştır. Friedman testi ile bir gruptan sıralı, skor ya da aralıklı ölçek ile elde edilen verilerin işlem etkileri veya işlem ortanca değerleri arasında farklı olup olmadığına bakılır (Özdamar, 2013). Böylece bu test ile bir gruptaki amaçların eşit önemli olup olmadığ Friedman testi için belirlenen hipotezler:

$\mathrm{H}_{0}$ : Üreticilerin arazi kullanım türlerini belirlerken yaptıkları tercihler arasında herhangi bir fark yoktur.

$\mathrm{H}_{1}$ : Üreticilerin arazi kullanım türlerini belirlerken yaptıkları tercihler arasında bir fark vardır.

Bir sütun içerisinde çiftçi sıralamasının uyumu Kendals W testi ile ölçülebilir (Legendre, 2005). Böylece üç ya da daha fazla kişi arasındaki uyum değerlendirilmiş olur (Özdamar, 2013).

\section{BULGULAR ve TARTIŞMA}

Çalışma kapsamında görüşülen üreticilere ait genel bulgular Çizelge 1'de sunulmuştur. Buna göre üreticilerin yaş ortalaması 53 'dür ve $\% 53,5$ 'inin eğitim seviyesi ilkokul düzeyindedir. Üreticilerin \%43'ü son bir yıl içerisinde tarımla ilgili herhangi bir eğitime katılmıştır, \%9,6'sının dergi ya da gazete gibi tarımsal bir yayına üyeliği bulunmaktadır ve $\% 39,5$ 'i tarımsal bilgiye ulaşmada internetten faydalanmaktadır (Çizelge 1).

Çalışma kapsamında çiftçilerin kendilerine ait olan arazi varlıklarına bakıldığında \%36,4'ünün sahip olduğu arazinin 1-50 dekar arasinda olduğu, \%23,4'ünün arazi varlığının 51-100 dekar arasında olduğu ve \%40,2'sinin arazi varlığının 100 dekardan fazla olduğu bulunmuştur. Çiftçilere sahip oldukları arazilerin parçalık durumu sorulduğunda ise ortalama arazi parça sayısının 8 olduğu tespit edilmiştir. Çalışma bölgesindeki çiftçiler mülk arazilerine ilave olarak kira ile de arazi işlemektedirler.

Çiftçilere kira ile işledikleri arazilerin büyüklükleri sorulduğunda \%52,8'inin 1-50 dekar arasında araziyi kira ile işlediği, \%16,9'unun 51-100 dekar arasında ve \%30,3'ünün de 100 dekardan fazla araziyi kira ile işledikleri bulunmuştur (Çizelge 2).

İncelenen işletmelerde üreticilerin sırası ile en çok buğday yetiştirmeyi tercih ettikleri bulunmuştur $(\% 32,50)$. Bunu sirasiyla misır $(\% 23,39)$, çeltik $(\% 19,12)$, ayçiçeği $(\% 9,62)$, domates $(\% 9,45)$ ve diğer ürünler takip etmektedir (Çizelge 3).

Çalışmada incelenen işletmeler arasında büyükbaş hayvan yetiştiriciliği yapanların \%64,71'inin sahip olduğu büyükbaş hayvan sayısı 20 baş ve daha az bulunmuştur. Küçükbaş hayvancıllk yapanların \%33,33'ünün küçükbaş hayvan sayısı 20 baş ve daha azdır (Çizelge 4).

Çizelge 1. Üreticilerin genel özellikleri.

Table 1. General characteristics of farmers

\begin{tabular}{lcr}
\hline $\begin{array}{l}\text { Kriterler } \\
\text { Criteria }\end{array}$ & $\begin{array}{c}\text { Say1 } \\
\text { Number }\end{array}$ & $\begin{array}{r}\text { Oran } \\
\text { Ratio }\end{array}$ \\
\hline Yaş aralığ1 (Y1l)/Age range (Years) & & \\
$<53$ & 50 & 43,9 \\
$>=53$ & 64 & 56,1 \\
Toplam (Total) & 114 & 100,0 \\
\hline En küçük: 29, En büyük: 77, Ortalama: 53, S. sapma: & 11,14 \\
(Min: 29, Max: 77, Mean: 53, Std. deviation: 11,14) & \\
\hline Eğitim durumu/Education status & & \\
Okur-yazar değil (Illiterate) & 1 & 0,9 \\
İlkokul (Primary school) & 61 & 53,5 \\
Ortaokul (Secondary school) & 15 & 13,2 \\
Lise (High school) & 25 & 21,9 \\
Üniversite (University) & 12 & 10,5 \\
\hline Son bir yılda tarımsal toplantılara katılma & \\
Participate to agricultural meetings in the last year & \\
Katılan (Participate) & 49 & 43,0 \\
Katılmayan (Non participate) & 65 & 57,0 \\
\hline Tarımsal yayına üyelik/Membership to agricultural \\
publication \\
Üye (Member) \\
Üye değil (Non- member) \\
İnternet kullanımi/Internet usage \\
Kullanan (User) \\
Kullanmayan (Non user) & 11 & \\
\hline & 103 & 90,6 \\
\hline
\end{tabular}

Çizelge 2. Arazi büyüklüğü-arazi tasarruf dağılımı.

Table 2. Land size-land possession distribution.

\begin{tabular}{|c|c|c|c|c|}
\hline \multirow{2}{*}{$\begin{array}{l}\text { Kriter } \\
\text { Criteria }\end{array}$} & \multicolumn{2}{|c|}{ Mülk arazi (Owned land) } & \multicolumn{2}{|c|}{ Kiralanan arazi (Leased land) } \\
\hline & Say1 / Number & Oran $(\%)$ / Ratio (\%) & Say1 / Number & Oran $(\%)$ / Ratio (\%) \\
\hline $1-50 \mathrm{da}$ & 39 & 36,4 & 47 & 52,8 \\
\hline $51-100 \mathrm{da}$ & 25 & 23,4 & 15 & 16,9 \\
\hline$>100 \mathrm{da}$ & 43 & 40,2 & 27 & 30,3 \\
\hline Toplam / Total & 107 & 100,0 & 89 & 100,0 \\
\hline
\end{tabular}


Çizelge 3. İşletmelerin üretim desenleri.

Table 3. Production patterns of businesses.

\begin{tabular}{lcccc}
\hline Ürün & $\begin{array}{c}\text { Çiftçi sayısı } \\
\text { Product }\end{array}$ & $\begin{array}{c}\text { Oran (\%) } \\
\text { Ratio (\%) }\end{array}$ & $\begin{array}{c}\text { Üretim alanı (da) } \\
\text { Production area (da) }\end{array}$ & $\begin{array}{c}\text { Oran (\%) } \\
\text { Ratio (\%) }\end{array}$ \\
\hline Arpa (Barley) & 18 & 4,48 & 592 & 2,25 \\
Ayçiçeği (Sunflower) & 54 & 13,43 & 2.525 & 9,62 \\
Biber (Pepper) & 29 & 7,21 & 359 & 1,37 \\
Buğday (Wheat) & 96 & 23,88 & 8.532 & 32,50 \\
Çeltik (Paddy) & 25 & 6,22 & 5.020 & 19,12 \\
Domates (Tomato) & 69 & 17,16 & 2.482 & 9,45 \\
Fiğ (Vetch) & 1 & 0,25 & 9 & 0,03 \\
Misır (Maize) & 81 & 20,15 & 6.140 & 23,39 \\
Yonca (Clover) & 11 & 2,74 & 210 & 0,80 \\
Karpuz (Watermelon) & 1 & 0,25 & 2 & 0,01 \\
Kavun (Melon) & 17 & 4,23 & 385 & 1,47 \\
\hline Toplam & & & & 100,00 \\
Total & 402 & 100,00 & 26.256 & \\
\hline
\end{tabular}

Çizelge 4. İşletmelerin hayvan varlıkları.

Table 4. Animal assets of businesses.

\begin{tabular}{lcc}
\hline $\begin{array}{l}\text { Büyükbaş hayvan sayıs1 } \\
\text { Number of cattle }\end{array}$ & $\begin{array}{c}\text { Say1 } \\
\text { Number }\end{array}$ & $\begin{array}{c}\text { Oran }(\%) \\
\text { Ratio (\%) }\end{array}$ \\
\hline $1-20$ & 11 & 64,71 \\
$21-50$ & 2 & 11,76 \\
$51-100$ & 3 & 17,65 \\
$>100$ & 1 & 5,88 \\
\hline Toplam (Total) & 17 & 100,00 \\
\hline Keçi ve koyun say1s1 & Say1 & Oran $(\%)$ \\
Number of goats and sheep & Number & Ratio (\%) \\
\hline $1-20$ & 6 & 33,33 \\
$21-50$ & 5 & 27,78 \\
$51-100$ & 4 & 22,22 \\
$101-200$ & 2 & 11,11 \\
$>200$ & 1 & 5,56 \\
\hline Toplam (Total) & 18 & 100,00 \\
\hline
\end{tabular}

Çalışmada işletmelerin tarımsal faaliyetleri sonucu elde ettikleri y1llık gelirler ele alınmıştır. Buna göre çiftçilerin \%7,9'unun yıllık tarımsal geliri 10.000 TL'den az, \%17,5'inin 10.000-20.000 TL arasında, \%26,3'ünün 20.001-50.000 TL arasında, $\% 22,8$ 'inin 50.001-100.000 TL arasinda ve \%25,4'ünün y1llık tarımsal geliri 100.000 TL'nin üzerinde tespit edilmiştir. Görüşülen çiftçilerin \%68,4'ünün ise emeklilik, kira vb. tarım dışı geliri bulunmaktadır (Çizelge 5).

Çalışmada çiftçilere arazi kullanım kararları olarak dört tercih sunulmuştur. Daha sonra bu tercihler arasında çiftçilerin eşli karşılaştırmalar yapmaları sağlanmıştır. Çiftçilerin bu tercihlere verdikleri cevapların ağırlıkları BEK yöntemiyle saptanmıştır. BEK yöntemi ile elde edilen tanımlayıcı istatistikler ise Çizelge 6'da sunulmuştur.
Çizelge 5. İşletmelerin gelir durumları.

Table 5. Income status of businesses.

\begin{tabular}{lcc}
\hline Yillık tarımsal gelir (TL) & Sayı & Oran (\%) \\
Annual agricultural income (TRY) & $\begin{array}{c}\text { Number } \\
\text { Ratio (\%) }\end{array}$ \\
\hline$<10000$ & 9 & 7,9 \\
$10000-20000$ & 20 & 17,5 \\
$20001-50000$ & 30 & 26,3 \\
$50001-100000$ & 26 & 22,8 \\
$>100000$ & 29 & 25,4 \\
\hline Tarım diş1 gelir varlığ & & \\
Off-farm income & & \\
\hline Evet (Yes) & 78 & 68,4 \\
Hayır (No) & 36 & 31,6 \\
\hline
\end{tabular}

Çiftçilerin arazi kullanım türlerine karar vermede etkili olabilecek tercihlerin;
1- Toprak özelliği
2- Alışkanlıklar
3- Pazarlama
4- Maliyet olabileceği kabul edilmiştir.

Literatürde çiftçilerin girdi kullanma kararlarını etkileyen faktörlerin araștırıldığı çalıșmalara (Aydın ve ark., 2016), çiftçilerin temel işletmecilik kararlarının bu kararları alırken destek bulmayı umdukları kurumlar açısından değerlendirdikleri çalışmalara (Günden ve Miran, 2008), çiftçilerin belirsiz iklim koşullarında yetiştirecekleri ürün kombinasyonlarının kararlarını ortaya koyan çalışmalara (Düzakın ve Bulğurcu, 2011) rastlamak mümkündür. $\mathrm{Bu}$ çalışmanın yeniliği ve literatüre yapacağ 1 katk1 çiftçilerin arazi kullanım türlerine karar vermelerinde etkili olan faktörlerin ortaya 
konmasıdır. Bir ișletme birden fazla girdi kullanarak belli bir ürün elde ederken üretimin maliyetini mümkün olan en düşük seviyede tutmalıdır (Türkay, 2010). İşletmenin üretim amacıyla yaptığ 1 her türlü giderin toplamı üretim maliyetini vermektedir (Pekin, 1999). Tarım işletmelerinde masraflar üretim faaliyetlerine dağıtılabilme özelliğine sahiptir (Kıral ve ark., 1999). Bir tarım işletmesinin masrafları üretim için kullanılan tohum, gübre, ilaç, işçilik, makine masrafi vb çeşitli masraflardır (İnan, 2016). Literatürde tarımsal üretim maliyetlerinin yüksekliğini ortaya koyan çeşitli çalışmalara rastlamak mümkündür (Karadaş, 2016; Candemir ve ark., 2017; Gül ve ark., 2017). Bu çalışmanın BEK yöntemi sonuçlarına göre de araştırma bölgesindeki çiftçilerin arazi kullanım türüne karar vermelerinde en etkili tercih sebebi "maliyet" tir. Çiftçiler öncelikle üretecekleri ürünlerin kendilerine olan maliyetlerine göre arazi kullanım türüne karar vermektedirler.

Çalışmada çiftçilere arazi kullanım türleri kararları için sunulan bir diğer kriter "pazarlama" kriteri olmuştur. Tarımsal pazarlama tarım ürünlerinin üreticiden son tüketiciye ulaştığı ana kadarki olayları inceleyen bir bilimdir (Güneş, 1996). Çiftçiler tarım ürünlerini yetiştirmek için büyük gayretler harcamakta fakat esas zorluğu mallarını pazarlarken yaşamaktadır (Everest, 2009). Tarımsal ürünlerin pazarlanmasında karşılaşılan sorunlara literatürde rastlamak mümkündür (Çimen, 2001; Dere, 2006; Yulafçı ve Cinemre, 2007; Adanacioğlu, 2014). Yapılan BEK analizine göre çalışma bölgesindeki çiftçilerin maliyetten sonra arazi kullanım türü kararında etkili olan ikinci önemli tercihleri "pazarlama" dır. Çiftçiler pazarlama kolaylığı olan ürünleri üretmeyi tercih etmektedirler.

Arazi kullanımındaki değişimin toprağın fiziksel ve kimyasal özelliklerinden etkilendiği bilinmektedir (Lauber ve ark., 2008). Yetiştiriciliği yapılan bitkinin iyi bir gelişim sağlaması yetiştiği toprak ortamının fiziksel ve kimyasal özellikleri ile ilişkilidir (Bender ve ark., 1998). Arazi kullanım yönetimiyle toprak kalitesi arasında güçlü bir ilişki vardır (Acosta-Martinez ve ark., 2007). Sürdürülebilir bir tarımsal üretim için bitkilerin gereksinimlerinin en uygun şekilde karşılanması gerekmektedir. Bir bitkinin optimum düzeyde yetiştiriciliğinin sağlanması için uygun fiziksel, kimyasal toprak özellikleri ve topoğrafik koşulları esas alan planlamalar yapılmalıdır. Bu çalışmada ise çiftçilerin arazi kullanım türlerine karar vermelerinde etkili olan üçüncü faktörün çiftçilerin sahip oldukları arazinin fiziksel, kimyasal ve topoğrafik olan "toprak özellikleri” olduğu tespit edilmiştir.

Çiftçiler genel olarak yeniliklere kapalı olup bildikleri/alışkın oldukları üretimleri yapmaya eğilimlidirler. Bu kapsamda çiftçi alıșkanlıkları arazi kullanım türünün belirlenmesinde etkilidir. Kızılaslan ve Ünal (2013)'e göre yenilikler ancak onu kullanacak olanlar tarafından benimsendiğinde veya uygulandığında bir yarar sağlayabilir. Karahan Uysal, (2015)'e göre çiftçi davranışlarını, ekonomik, sosyal, kültürel, politik ve coğrafi olmak üzere pek çok etkileyen vardır. Ataerkil aile biçiminin kırsalda varlığını hala önemli ölçüde sürdürmesi, üretim sisteminin doğaya bağlılığı, insanlar arası ilişki ve etkileşim sistemlerinin özgünlügü gibi nedenlerle, kırsal kesimde başlıca ekonomik aktör durumundaki çiftçinin ekonomik kararlarında rasyonelliğin ötesinde, bu davranıșsal ögelerin de belirgin yansımaları vardır. Ayrıca yayım faaliyetleri ile çiftçilere sunulan önerilerin benimsenmesi ve uygulanması konusunda çiftçilerin ikna edilmesi çok kolay olmamaktadır (Sezgin ve ark., 2010). Benzer çalışmalar da aynı sonuçlara ulaşmışlardır (Aktaş, 2004; Boyacı, 2002; İmamoğlu ve Çobanoğlu, 2018; Demirtaş ve ark., 2016). Çalışmada çiftçilerin arazi kullanım türlerine karar vermelerinde etkili olan dördüncü faktör "alışkanlıklar" olarak tespit edilmiştir.

Çizelge 6. BEK yöntemine göre çiftçilerin arazi kullanım tercihleri.

Table 6. Land use preferences of farmers according to BEK method.

\begin{tabular}{lcccc}
\hline Tercihler & Toprak Özelliği & Alıskanlıklar & Pazarlama & Maliyet \\
Preferences & Soil properties & Habits & Marketing & Cost \\
\hline Ortalama (Mean) & 0,36 & 0,28 & 0,48 & 0,50 \\
Standart sapma (St. deviation) & 0,31 & 0,28 & 0,28 & 0,31 \\
En küçük (Min) & 0,00 & 0,00 & 0,00 & 0,00 \\
En büyük (Max) & 1,00 & 1,00 & 1,00 & 1,00 \\
\hline p & & &
\end{tabular}

$\mathrm{p}$ değeri Friedman testine göre anlamlıdır $(\mathrm{p}<0,01)$ [p valeu is significant according to Friedman test $(\mathrm{p}<0,01)]$;

Kendall's $\mathrm{W}$ değeri $=0,121$ (Kendall's $\mathrm{W}$ value $=0,121$ ). 
İlave olarak Friedman testine göre yöntem istatistiksel açıdan anlamlıdır. Yani çiftçi tercihlerinin bazıları diğerlerine göre daha öncelikli olarak tercih edilmektedir. Çiftçilerin arazi kullanım tercihlerinde istatistiki olarak anlamlı bir fark bulunmuştur. Kendall's W değeri ise 0,121 'dir. Yani çiftçilerin karar sıralamaları arasındaki uyum zayıftır (Çizelge 6).

\section{SONUÇ ve ÖNERILER}

Çanakkale iline polikültür tarımın yapıldığı bölgelerden biri olan çalışma bölgesinde çiftçilerin arazi kullanım türlerine karar vermelerinde etkili olan faktörlerin incelenmesi neticesinde çiftçilerin öncelikle maliyet unsuruna göre karar verdikleri ortaya çıkmıştır. Dolayısıyla tarım sektöründe maliyetleri düşürücü politikaların yürütülmesi önem taşımaktadır. Üretim planlamasının yapılacağı çalışmaların çiftçiler tarafindan benimsenmesinde de üretim maliyetlerinin etkili olacağı unutulmamalıdır. Şüphesiz üretim maliyetlerinin yüksekliği tarım sektöründe çiftçileri en çok zorlayan unsurdur. Çiftçiler üretimde kullanacaklanı tohum, gübre, ilaç, işçilik vb maliyetleri göz önünde tutarak ve sahip oldukları sermayeyi değerlendirerek üretimlerini şekillendirmektedirler. Yani tarımsal girdilerin maliyeti söz konusu ürünlerin arz miktarların etkilemektedir. Buradan yola çıkarak polikültür

\section{LITERATÜR LISSTESI}

Abacı, N. İ., and K. Demiryürek. 2019. Factors affecting farmers' decision making on product pattern: A case of vegetable producers in Bafra District of Samsun Province, Turkey. Turkish Journal of Agriculture-Food Science and Technology 7 (3): 426-434. Doi: 10.24925/turjaf.v7i3.426-434.2359.

Acosta-Martinez, V., L. Cruz, D. Sotomayor-Ramirez, and L. Pérez-Alegría. 2007. Enzyme activities as affected by soil properties and land use in a tropical watershed. Applied Soil Ecology 35 (1): 35-45. Doi: 10.1016/ j.apsoil.2006.05.012.

Adanacıŏlu, H. 2014. Tarımsal ürünlerde doğrudan pazarlama kavramı ve pazarlama etkinliği açısından dolaylı pazarlama ile karşılaştırılmalı analizi: İzmir ili Urla ilçesi Balıklıva köyü örneği. XI. Ulusal Tarım Ekonomisi Kongresi, Konya.

Aktaş, Y. 2004. Tarımsal yayım sürecinde davranış ve değişimi. Tarım Ekonomisi Dergisi (9): 17-27.

Anonim, 2018. Çanakkale İl Tarım ve Orman Müdürlüğü 2018 Y1lı Brifing Raporu. Çanakkale, Türkiye. tarımın yapıldığı bölgelerde arz açığı olan ürünlerin daha fazla tarımsal destekleme ile dengeye ulaşacağı söylenebilir. Diğer taraftan üretilen ürünlerin kolayca pazarlanıyor olması da tarımsal arzı şekillendiren bir unsurdur. Tarımda başarılı kooperatif örneklerinde olduğu gibi etkili pazarlama kanallarının yaygınlaştırılması önem taşımaktadır. Bunun başarılması için bölgedeki kooperatiflerin pazarlama konusunda aktif hale gelmesi gerekmektedir. Çiftçilerin üçüncü olarak topraklarının özelliklerine göre arazi kullanım türlerine karar verdikleri düşünüldüğünde toprak özelliğinin pazarlama ve maliyet kriterlerinden daha sonra dikkate alındığ 1 ortaya çıkmıştır. Arazilerin yetenek ve kapasiteleri dışında kullanılması arazilerin degradasyona uğramasına neden olabilecek tehlikeli bir faktördür. Toprak özellik ve yeteneklerinin esas alınmadığı üretim sistemlerinde çeşitli düzeylerde başarısızlıklar yaşanmaktadır. $\mathrm{Bu}$ kapsamda bölgede çiftçilerin toprak özelliklerini bilme durumlarına ilişkin yeni çalışmaların yapılması ilaveten çiftçi eğitim ve yayım faaliyetlerinde arazi yönetiminde toprak özelliklerinin öneminin vurgulayan eğitimler yapılmalıdır. Çiftçi alışkanlıkların arazi kullanım türüne karar vermede son sırada yer alması bölgedeki çiftçilerin yeniliklere açık olduğunu göstermektedir. O halde yeni ürün ya da teknolojinin benimsenmesi konusunda araştırma bölgesi ideal olabilir.

Aydın, B., G. Unakıtan, F. Yılmaz, Ö. Azabağaoğlu ve C. Demirkol. 2016. Bitkisel üretimde çiftçilerin girdi kullanım kararlarının analizi: Trakya Bölgesi örneği. Uludağ Üniversitesi Ziraat Fakültesi Dergisi 30 (2): 45-56.

Baijmol, W. J. 1972. Economic Theory and Operations Analysis. Prentice-Hall, Inc., Englewood Cliffs, New Jersey.

Balent, G., and D. M. S. Smith. 1993. Conceptual model for evaluating the consequences of management practices on the use of pastoral resources. Proceedings of the International Rangeland Congress, http://hdl.handle. net/102.100.100/251508? index $=1$.

Bender, D., İ. Erdal, O. Dengiz, M. Gürbüz ve C. Tarakçığlu. 1998. Farklı organik materyallerin killi bir toprağın bazı fiziksel özellikleri üzerine etkileri. International Symposium On Arid Region Soil, İzmir.

Bourbouze, A., and A. Gibon. 1999. Ressources individuelles ou ressources collectives? L'impact du statut des ressources sur la gestion des systèmes d'élevage des régions $\mathrm{du}$ pourtour méditerranéen. Options méditerranéennes (27): 289-309. 
Boyacı, M. 2002. Araştırma-yayım-çiftçi ilişkilerinin kurumsallaşması: İsrail bölgesel araştırma-geliştirme merkezleri örneği. Ege Üniversitesi Ziraat Fakültesi Dergisi 39 (3): 80-87.

Candemir, S., N. Kizılaslan, H. Kizılaslan, O. Uysal, ve M. Aydoğan. 2017. Kahramanmaraş ilinde dane misır ve pamuk üretiminde girdi gereksinimi ve karlılıkları açısından karşılaştırmalı analizi. Türk Tarım ve Doğa Bilimleri Dergisi 4 (1): 1-8.

Çimen, Z. A. 2001. Antalya İli Kumluca İlçesindeki sera üreticilerinin pazarlama sorunları. Akdeniz Universites Iktisadi ve Idari Bilimler Fakultesi Dergisi 1 (1): 1-14.

Demirtaş, M., R. Demirtaş ve O. S. Subaşı. 2016. Türkiye'de araştırmac1-yayımc1-çiftçi bağının güçlendirilmesi çalışmaları. 12. Ulusal Tarım Ekonomisi Kongresi, Isparta.

Dere, H. E. 2006. Tarımsal pazarlama sorunları ve sultandağ kirazı üzerine bir araştırma. Yüksek Lisans Tezi, Afyon Kocatepe Üniversitesi, Sosyal Bilimler Enstitüsü, Afyon, Türkiye.

Düzakın, E. ve B. K. Bulğurcu. 2011. Tarımsal karar analizi. Cukurova Üniversitesi Sosyal Bilimler Enstitüsü Dergisi 20 (3): 233-252.

Everest, B. 2009. Tarımsal ürünlerin pazarlanmasında çiftçi örgütlerinin rolü ve önemi: Çanakkale tarımsal kalkınma kooperatifleri örneği. Yüksek Lisans Tezi, Çanakkale Onsekiz Mart Üniversitesi, Fen Bilimleri Enstitüsü, Çanakkale - Türkiye.

Foley, J. A., R. DeFries, G. P. Asner, C. Barford, G. Bonan, S. R. Carpenter, F. S. Chapin, M. T. Coe, G. C.Daily, H. K. Gibbs, J. H. Helkowski, T. Holloway, E. A. Howard, C. J. Kucharik, C. Monfreda, J. A. Patz, L. C. Prentice, N. Ramankutty, and P. K. Snyder. 2005. Global consequences of land use. Science (309): 570 574. Doi: 10.1126/science.1111772.

Ganzert, C. 1995. Konzeption für eine ökologische agrarlandschaftsforschung. Berichte der ANL, Beiheft (12): 51-64

Gül, M., H. Parlak, and H. Öktem. 2017. The cost and profit of fennel production: A case study of Burdur province of Turkey. International Journal of Advances in Agricultural \& Environmental Engg 4 (1): 2349-1531. Doi: 10.15242//3AAEE.AE/216421.

Günden, C. ve B. Miran. 2008. Bulanık analitik hiyerarşi süreci kullanılarak çiftçi kararlarının analizi. Ege Üniversitesi Ziraat Fakültesi Dergisi 45 (3): 195-206.

Güneș, T. 1996. Tarımsal Pazarlama. Ankara Üniversitesi Ziraat Fakültesi Yayınları. Yayın No: 1467.

İmamoğlu, H., ve F. Çobanoğlu. 2018. Balıkesir ilinde tarımsal danışmanlık hizmetinin etkisinin değerlendirilmesi. Harran Tarım ve Gida Bilimleri Dergisi 22 (2): 263-274. Doi.10.29050/ harranziraat.325094.

İnan, İ. H. 2016. Tarım Ekonomisi ve İşletmeciliği. İdeal Kültür\&Yayın, Tekirdağ.

Karadaş, K. 2016. Ağrı ili tarım işletmelerinde buğday üretim maliyetinin hesaplanması. Alinteri 31 (B): 33-41.
Karahan Uysal, Ö. 2015. Manisa ili Yunt Dağı köylerinde çiftçilerin tarımsal üretime yaklaşımlarını etkileyen faktörlerin analizi. Sosyal ve Beşeri Bilimler Araştırmaları Dergisi 1 (35): 73-95.

Kıral, T., H. Kasnakoğlu, F. Tatlıdil, H. Fidan ve E. Gündoğmuş. 1999. Tarımsal Ürünler İçin Maliyet Hesaplama Metodolojisi ve Veri Tabanı Rehberi. Tarımsal Ekonomi Araştırma Enstitüsü Proje Raporu, Ankara -Türkiye.

Kızılaslan, N. ve Y. Ünal. 2013. Çiftçilerin tarımsal yayım farkındalıklarının belirlenmesi (Tokat/Erbaa örneği). Gaziosmanpaşa Bilimsel Araştırma Dergisi (5): 1-19.

Klein, G. A., J. Orasanu, R. Calderwood, and C. E. Zsambok. 1993. Decision Making in Action: Models and Methods. Westport, CT, US: Ablex Publishing.

Lauber, C. L., M. S. Strickland, M. A. Bradford, and N. Fierer. 2008. The influence of soil properties on the structure of bacterial and fungal communities across land-use types. Soil Biology and Biochemistry 40 (9): 24072415. Doi: 10.1016/j.soilbio.2008.05.021.

Legendre, P. 2005. Species associations: The Kendall coefficient of concordance revisited. Journal of Agricultural, Biological and Environmental Statistics 10 (2): 226 - 245. Doi: 10.1198/108571105X46642.

Mottet, A., S. Ladet, N. Coqué, and A. Gibon. 2006. Agricultural land-use change and its drivers in mountain landscapes: a case study in the Pyrenees. Agriculture, Ecosystems \& Environment 114 (2-4): 296-310. Doi: 10.1016/j.agee.2005.11.017.

Neumann, J. V., and O. Morgenstern. 1947. Theory of Games and Economic Bahvior, 2nd ed., Princeton University Press, Princeton, NJ.

Newbold, P. 1995. Statistics for Business and Economics, Prentice Hall Inc., USA. Pages 1016.

Özdamar, K. 2013. Paket Programları İle İstatistiksel Veri Analizi. Nisan Kitabevi. Türkiye.

Pekin, T. 1999. Ekonomiye Giriş. Bilgehan Matbaas1, Bornova, İzmir.

Ravnborg, H. M., and J. E. Rubiano. 2013. Farmers' decision making on land use the importance of soil conditions in the case of Río Cabuyal watershed, Colombia. Journal of Geography 101 (1): 115-130. Doi: 10.1080/00167223.2001.10649455.

Sezgin, A., E. T. Kaya, M. Külekçi, and H. Kumbasaroğlu. 2010. Tarımsal yeniliklerin benimsenmesinde etkili olan faktörlerin analizi: Erzurum ili örneği, Türkiye IX. Tarım Ekonomisi Kongresi, Şanlıurfa, Türkiye.

Türkay, O. 2010. İktisat Teorisine Giriş Mikroiktisat. İmaj Yayınevi. Ankara, Türkiye.

Yulafçı, A. ve H. Cinemre 2007. Çarşamba Ovasında Yaş Meyve Ve Sebze Pazarlama Sorunları. Anadolu Tarım Bilimleri Dergisi 22 (3): 260-268.

Zadeh, L. A. 1965, Fuzzy sets. Information and Control (8): 338-353.

Zander, P., and H. Kächele. 1999. Modelling multiple objectives of land use for sustainable development. Agricultural Systems 59 (3): 311-325. Doi: 10.1016/S0308-521X(99)00017-7. 